\title{
MENINGKATKAN KEMAMPUAN SISWA KELAS I DALAM MENGOPERASIONALKAN PENJUMLAHAN DAN PENGURANGAN PADA MATA PELAJARAN MATEMATIKA DENGAN BANTUAN BENDA-BENDA KONGKRIT SD NEGERI 200310 PUDUN JULU PADANGSIDIMPUAN TAHUN PELAJARAN 2015/2016
}

\author{
UMMI HASIBUAN, S.Pd \\ NIP. 196605201986042002 \\ Email: ummihasibuan9@gmail.com
}

\begin{abstract}
abstrak
Rumusan masalah dalam penelitian ini adalah bagaimana penggunaan benda-benda kongkrit mampu meningkatkan kemampuan siswa Kelas I SD Negeri 200310 Pudun Julu Padangsidimpuan dalam mengoperasionalkan penjumlahan dan pengurangan pada mata pelajaran Matematika. Penelitian ini bertujuan untuk meningkatkan kemampuan siswa dalam mengoperasionalkan penjumlahan dan pengurangan dengan bantuan benda-benda kongkrit, juga diharapkan bermanfaat bagi siswa, peneliti,maupun orang tua murid. Untuk mencapai tujuan tersebut dilakukan penelitian tindakan kelas terhadap Siswa kelas I SD Negeri 200310 Pudun Julu Padangsidimpuan sebanyak 20 siswa yang dilakukan dalam 2 siklus.

Metode yang digunakan dalam penelitian ini adalah pendekatan kualitatif yang menggambarkan masalah sebenarnya yang ada dilapangan kemudian di refleksikan dan dianalisis berdasarkan teori yang menunjang dilanjutkan dengan pelaksanaan penelitian dilapangan. Data yang diperoleh dalam penelitian ini melalui observasi pengamatan diskusi dan evaluasi.

Hasil penelitian ini menunjukkan peningkatan dari kegiatan pratindakan, siklus I dan siklus II. Dalam penelitian pratindakan siswa yang mengalami ketuntasan belajar sebanyak $65 \%$ setelah dilakukan tindakan Siklus I dengan alat bantu benda-benda kongkrit. Ketuntasan belajar siswa dalam siklus II naik menjadi $90 \%$ dilanjutkan siklus selanjutnya seluruh siswa mengalami ketuntasan belajar.

Kesimpulan yang dapat diambil adalah bahwa benda-benda kongkrit dapat membantu siswa dalam mengoperasionalkan penjumlahan dan pengurangan bilangan pada pembelajaran Matematika Kelas I, sehingga prestasi belajar mengalami kemajuan. Temuan yang lain anak menjadi senang, percaya diri dalam melakukan proses pembelajaran.

Dengan demikian dapat disarankan bahwa pelaksanaan pendidikan hendaknya berwawasan lingkungan karena lingkungan banyak menyediakan alat bantu yang murah, mudah didapat dan mudah dikenal anak.
\end{abstract}

\section{PENDAHULUAN}

Pendidikan merupakan usaha manusia untuk menyiapkan diri dalam perananya dimasa akan datang. Pendidikan dilakukan tanpa ada batasan usia, ruang dan waktu yang tidak dimulai atau diakhiri di sekolah, tetapi diawali dalam keluarga dilanjutkan dalam lingkungan sekolah dan diperkaya oleh lingkungan masyarakat, yang hasilnya digunakan untuk membangun kehidupan pribadi agama, masyarakat, keluarga dan negara. Merupakan suatu kenyataan bahwa pemerintah dalam hal ini diwakili lembaga yang bertanggung jawab didalam pelaksanaan pendidikan di Indonesia, akan tetapi pendidikan menjadi tanggung jawab keluarga, sekolah dan masyarakat yang sering disebut dengan Tri Pusat Pendidikan.

Salah satu keprihatinan yang dilontarkan banyak kalangan adalah mengenai rendahnya mutu pendidikan atau Out Put yang dihasilkan oleh lembaga-lembaga pendidikan formal. Dalam hal ini yang menjadi kambing hitam adalah guru dan lembaga pendidikan tersebut, orang tua tidak memandang aspek keluarga dan kondisi lingkungannya. Pada hal lingkungan keluarga dan masyarakat sekitar sangat menentukan terhadap keberhasilan pendidikan. 
Memasuki Tri bulan pertama tahun 2015/2016, ketika diadakan Ulangan Tengah Semester mulai tampak timbul suatu masalah. Sewaktu ulangan jatuh pada mata pelajaran Matematika begitu naskah dibagikan, sebagian siswa berteriak-teriak memanggilmanggil ibunya, ada yang garuk-garuk kepala, juga tidak sedikit yang menangis karena merasa tidak bisa mengerjakan. Akhirnya nilai yang diperoleh oleh sisa kelas I dalam pelajaran matematika khususnya dalam mengoperasionalkan penjumlahan dan pengurangan. Nilai dari 20 siswa sebagai berikut: (1) 80-100 Amat baik ada 4 siswa = $20 \%$. (2) 55-79 Cukup ada 6 siswa $=30 \%$. (3) $0-54$ Kurang ada 10 siswa $=50 \%$. Dengan kondisi nilai tersebut diatas guru sebagai peneliti merasa pembelajaran matematika dikelas I kurang berhasil.

Selama ini peneliti sudah menggunakan berbagai macam metode untuk mencapai tujuan pendidikan yang diharapkan, tetapi hasilnya masih belum memuaskan. Agaknya memang strategi/pendekatan-pendekatan saja belum cukup untuk menghasilkan perubahan. Meier (2002 : 54) mengatakan bahwa belajar adalah berkreasi bukan mengkonsumsi. Pengetahuan bukanlah suatu yang diserap oleh pembelajaran, melainkan sesuatu yang diciptakan oleh pembelajar.

Pembelajaran terjadi ketika seseorang pembelajar memadukan pengetahuan dan keterampilan baru kedalam struktur dirinya sendiri yang telah ada. Belajar berharfiah adalah menciptakan makna baru, sejauh ini pendidikan kita didominasi oleh pandangan bahwa pengetahuan sebagai perangkat faktafakta yang harus dihafal. Kelas masih berfokus pada guru sebagai sumber utama pengetahuan. Kemudian ceramah menjadi pilihan utama strategi belajar. Untuk itu diperlukan strategi belajar baru yang memberdayakan siswa sebuah strategi belajar tidak mengharuskan siswa menghafalkan fakta-fakta tetapi sebuah strategi yang mendorong siswa mengkonstruksikan pengetahuan dibenak mereka sendiri.

Dalam upaya itu siswa perlu guru sebagai pengarah dan pembimbing. Dalam kelas tugas guru adalah membantu siswa mencapai tujuan. Maksudnya guru lebih banyak berurusan dengan strategi dengan alat bantu yang dikenal siswa disekitarnya, dari pada memberi informasi.memang pendidikan siswa kelas I Sekolah Dasar masih identik dengan dunia bermain, karena siswa kelas I belum dapat melepas keterkaitannya dengan pendidikan Taman Kanak-Kanak sebelumnya, karena itu benda-benda disekitar sekolah sangat membantu proses pembelajaran siswa.

Bertitik tolak dari latar belakang masalah di atas peneliti ingin meningkatkan kemampuan siswa kelas I Sekolah Dasar dalam mengoperasionalkan penjumlahan dan pengurangan pada mata pelajaran Matematika dengan bantuan benda-benda kongkrit.

\section{METODE PENELITIAN}

Pendekatan yang digunakan dalam penelitian ini adalah pendekatan Kualitatif yaitu menggambarkan masalah sebenarnya yang ada di lapangan, kemudian direfleksikan dan dianalisis berdasarkan teori menunjang dilanjutkan dengan pelaksanaan tindakan di lapangan. Pendekataan Kualitatif dalam penelitian ini digunakan untuk menelusuri dan mendapatkan gambaran secara jelas tentang situasi kelas dan tingkah laku siswa selama proses pembelajaran berlangsung. Penelitian Tindakan Kelas dilaksanakan secara bersiklus. Pembelajaran dilakukan di kelas I SD Negeri 200310 Pudun Julu Padangsidimpuan.

Jenis penelitian yang digunakan dengan Penelitian Tindakan Kelas (PTK) karena ingin menerapkan pembelajaran untuk meningkatkan kemampuan siswa kelas I dalam mengoperasionalkan penjumlahan dan pengurangan bilangan dengan alat bantu benda-benda kongkrit di sekitar sekolah.

\section{HASIL DAN PEMBAHASAN}

Sesuai dengan tahap pembelajaran penjumlahan dan pengurangan bilangan dilakukan dalam 2 siklus dengan 5 kali pertemuan

\section{Siklus I}

A. Pertemuan I

- Apersepsi dengan alokasi waktu 10 menit diisi dengan kegiatan :

a. Peneliti masuk kelas dengan 2 orang pengamat tepat pukul 08.00 dilanjutkan dengan ucapan selamat. 
b. Peneliti mengajak subyek penelitian untuk berdoa bersama-sama agar memperoleh ilmu yang bermanfaat.

c. Peneliti mengabsen subyek penelitian satu persatu.

d. Peneliti mengulas kembali pelajaran yang lalu dengan mengembangkan pola tanya jawab mengenai penjumlahan dan pengurangan bilangan tanpa menggunakan alat bantu benda kongkrit untuk mengukur sejauh mana penguasaan anak-anak tentang penjumlahan dan pengurangan bilangan.

- Pelaksanaan Proses Belajar Mengajar dengan alokasi waktu 40 menit

a. Peneliti mengajak sisa bersama-sama menghitng kerikil yang diberikan oleh peneliti.

b. Peneliti menjelaskan cara mengoperasionalkan penjumlahan dan pengurangan bilangan dengan alat bantu kerikil.

Contoh : $6+4=\ldots$. berarti :

Ambil kerikil 6, ambil lagi kerikil 4. Berapa banyak kerikil semuanya?

$18-9=\ldots . .$. berarti :

Sediakan kerikil 18 ambil 9. Berapa sisa kerikil ?

c. Peneliti membimbing siswa bersamasama tentang penjumlahan dan pengurangan bilangan dengan alat bantu benda kerikil.

d. Beberapa siswa diberi kesempaatan mendemonstrasikan penjumlahan dan pengurangan bilangan dengan alat bantu kerikil didepan kelas diikuti oleh seluruh siswa dalam kelas.

e. Siswa mengerjakan Lembar Kegiatan Siswa secara individual dengan alokasi waktu 20 menit.

f. Peneliti berkeliling dengan dibantu pengamat untuk memberi bimbingan kepada siswa dalam mengerjakan LKS secara individual

B. Pertemuan II

- Apersepsi dengan alokasi waktu 10 menit digunakan untuk :

a. Mengulas materi penjumlahan dan pengurangan bilangan yang dijelaskan waktu yang lalu secara singkat sambil melakukan tanya jawab terhadap siswa.

b. Memberi kesempatan kepada siswa untuk tampil didepan kelas menyelesaikan soal materi yang lalu dengan alat bantu benda kerikil.

- Pelaksanaan Proses Belajar Mengajar Dengan alokasi waktu selama 40 menit.

a. Peneliti menjelaskan tentang penjumlahan dan pengurangan bilangan 3 angka dengan hasil kurang dari 20 dengan alat bantu benda kerikil

Contoh : $6+4+5=\ldots \ldots$ berarti :

Ambil kerikil 6, ambil lagi 4, ambil lagi

5. Berapakah banyak kerikil semuanya ?

$19-5-4=\ldots . .$. berarti :

Sediakan kerikil 19, ambil 5, ambil lagi

4. Berapakah sisa kerikilnya ?

b. Peneliti mengajak siswa bersama-sama melakukan penjumlahan dan pengurangan 3 angka dengan alat bantu benda kerikil.

c. Peneliti mendemonstrasikan penjumlahan dan pengurangan bilangan 3 angka didepan kelas diikuti seluruh siswa.

d. Siswa diberi kesempatan untuk tampil didepan kelas menyelesaikan soal soal latihan dibawah bimbingan peneliti.

e. Siswa mengerjakan LKS secara individual di bawah bimbingan peneliti dibant pengamat.

f. Peneliti berkeliling untuk mengawasi siswa dalam mengoperasionalkan penjumlahan dan pengurangan bilangan dengan alat bantu benda kerikil.

- Evaluasi dengan alokasi waktu 20 menit :

a. Alat evaluasi berupa Lembar soal dengan sistim penilaian betul 1 nilai 1 , salah 1 nilai kurang 1

b. Banyak soal 10 nomor.

c. Evaluasi dilaksanakan dengan tujuan untuk mengukur keberhasilan selama proses pembelajaran tentang penjumlahan dan pengurangan bilangan dengan alat bantu benda kongkrit kerikil.

d. Hasil evaluasi digunakan sebagai pembanding dengan evaluasi berikutnya untuk mengetahui keberhasilan dan ketuntasan belajar

\subsection{Tindakan}

a. Siswa melakukan proses penjumlahan dan pengurangan bilangan dengan 
menggunakan alat bantu benda kongkrit kerikil.

b. Peneliti melakukan bimbingan untuk mengoperasionalkan penjumlahan dan pengurangan bilangan dengan alat bantu benda kongkrit sambil melakukan penilaian proses.

c. Siswa mengerjakan LKS secara individual dengan alat bantu kerikil.

d. Siswa mengerjakan soal evaluasi.

1.3 Pengamatan

a. Aktivitas dan tingkah laku siswa selama proses belajar mengajar berlangsung oleh peneliti dibant oleh pengamat.

b. Hasil catatan selama melakukan pengamatan digunakan sebagai bahan diskusi

\subsection{Refleksi.}

a. Catatan dari Observer direnungkan dan dikaji kembali untuk bahan perbaikan pada siklus berikutnya.

b. Mengadakan remidial terhadap siswa yang mengalami kesulitan dalam belajar.

c. Semua siswa aktif melakukan pembelajaran Matematika dengan menggunakan alat bantu benda-benda kerikil.

d. Semua siswa mampu mengoperasionalkan penjumlahan dan pengurangan bilangan dengan hasil kurang dari 20 melalui alat bantu benda kongkrit kerikil.

e. Pada siklus berikutnya perlu diadakan penggantian alat bantu, misalnya abakus atau sempoa.

f. Materi pembelajaran ditingkatkan taraf kesulitannya, bila perlu soal-soal cerita disampaikan untuk mengetahui sejauh mana anak memahami bacaan .

g. Nilai yang diperoleh selama evaluasi oleh siswa telah memenuhi standar terrendah > 70 sebagai tolok ukur ketuntasan belajar.

\subsection{Paparan Data dan Temuan Pada Kegiatan Siklus II}

Siklus II

Sebagai mana yang dijelaskan dimuka bahwa siklus II terdiri dari 4 tahapan dalam 3 pertemuan yaitu :

\section{A. Pertemuan I}

- Apersepsi dengan alokasi waktu 10 menit digunakan untuk :

a. Mengulas materi penjumlahan dan pengurangan bilangan secara singkat sambil melakukan tanya jawab.

b. Memberi kesempatan kepada siswa untuk tampil di depan kelas menyelesaikan soal yang diberikan oleh peneliti.

- Proses belajar mengajar dengan alokasi waktu selama 45 menit digunakan untuk:

a. Memperkenalkan kepada siswa tentang penjumlahan dan pengurangan bilangan antara 2 sampai 3 angka dengan pola bersusun.

b. Memberi kesempatan kepada siswa untuk tampil di depan kelas menyelesaikan soal yang diberikan peneliti dengan alat bantu buah nyamplung.

c. Peneliti dibantu pengamat membimbing siswa satu persatu dalam menyelesaikan Lembar Kegiatan Siswa.

\section{B. Pertemuan II.}

- Apersepsi dengan alokasi waktu 10 menitt digunakan untuk :

a. Menjelaskan secara singkat materi penjumlahan dan pengurangan yang secara singkat dengan tanya jawab.

b. Memperkenalkan kepada siswa tentang proses penjumlahan dan pengurangan bilangan dengan pola mencari suku yang belum diketahui :

Contoh : $1 \ldots . .+9=18$

2. $19-\ldots=12$

3. $16-\ldots=9$

$4 \ldots . .+8=20$

5. $16-\ldots \ldots .-4=6$

c. Menjelaskan proses penjumlahan dan pengurangan bilangan dengan pola mencari suku yang belum diketahui melalui alat bantu buah nyamplung. Misal : ......+ $8=17$ berarti : Sediakan buah nyamplung sebanyak 17, ambil 8. Berapa sisa buah nyamplungnya?

d.Siswa mendemonstrasikan di depan kelas tentang pengoperasian penjumlahan dan pengurangan bilangan dengan buah nyamplung 
e.Siswa mengerjakan Lembar Kegiatan Siswa secara individual dibawah bimbingan peneliti dibantu pengamat dengan menggunakan alat bantu buah nyamplung.

\section{Pertemuan III}

- Apersepsi dengan alokasi waktu 10 menit diisi dengan :

a. Mengulas secara singkat materi yang lalu tentang penjumlahan dan pengurangan bilangan dengan tanya jawab.

b. Memberi kesempatan kepada siswa untuk menyelesaikan soal di depan kelas.

c. Memperkenalkan pola penjumlahan dan pengurangan dalam bentuk soal cerita.

- Pelaksanaan proses pembelajaran lama waktu yang digunakan 40 menit digunakan untuk:

a. Menjelaskan penjumlahan dan pengurangan dalam bentuk soal cerita. Contoh : Toni mempunyai 5 butir kelereng merah 3 kelereng biru dan 6 kelereng putih. Berapa banyak kelereng toni ?

b. Siswa mengerjakan LKS dengan bimbingan peneliti.

c. Peneliti mengajak siswa tampil didepan kelas ntuk menyelesaikan soal dibawah bimbingan peneliti.

- Evaluasi waktu yang digunakan 20 menit

Evaluasi ini dilakanakan setelah perjalanan siklus II berakhir dan dilakukan dengan tujuan untuk :

a. Mengkur keberhasilan proses pembelajaran siswa.

b. Hasil penilaian dijadikan tolak ukur perbandingan dengan siklus I ada kenaikan atau tidak.

2.2 Tindakan :

a. Siswa mengoperasionalkan penjumlahan dan pengurangan bilangan dengan alat bantu buah nyamplung.

b. Siswa mengerjakan Pelajaran LKS di bawah bimbingan peneliti dibantu pengamat.

c. Peneliti membimbing siswa dalam melakukan proses pembelajaran.
2.3 Tindakan :

a. Peneliti dan pengamat mencatat semua tingkah laku / kegiatan siswa selama proses pembelajaran berlangsung.

b. Melakukan diskusi bersama-sama membahas temuan-temuan / kejadiankejadian selama proses berlangsung.

c. Mengambil kesimpulan bersama-sama.

\subsection{Refleksi :}

a. Proses pembelajaran berlangsung semakin aktif semua siswa sibuk dengan tugas-tugas dihadapi.

b. Alat bantu benda-benda kongkrit sangat membantu proses pembelajaran.

c. Ketuntasan belajar siswa semakin meningkat.

d. Dengan bantuan / bimbingan peneliti dan pengamat siswa yang mengalami keterlambatan berfikir mengalami kemajuan dalam belajar.

e. Melakukan kegiatan remidial terhadap siswa mengalami keterlambatan belajar.

\subsection{Paparan Data akhir tindakan.}

Setelah kegiatan siklus I dan siklus II berakhir, peneliti membandingkan hasil evaluasi dari test awal penelitian, evaluasi tindakan siklus I dan dilanjutkan dengan hasil evaluasi tindakan siklus II. Dari test awal/ pratindakan menunjukkan siswa yang mengalami ketuntasan belajar berkisar $40 \%$. Untuk siklus I setelah tindakan dilaksanakan ketuntasan belajar siswa mengalami kenaikan menjadi $65 \%$ sedangkan hasil evaluasi siklus II seluruh siswa mengalami ketuntasan dalam belajar. Dari data yang diuraikan diatas menunjukkan bahwa dengan alat bantu benda-benda kongkrit dapat meningkatkan kemampuan siswa dalam penjumlahan dan pengurangan bilangan. 


\section{PEMBAHASAN}

Bila dilihat dari rumusan masalah yang dijelaskan sebelumnya, maka pembahasan dapat diuraikan menjadi dua bagian yaitu:

1. Penggunaan benda-benda kongkrit mampu meningkatkan kemampuan belajar.

Kegiatan pembelajaran dalam upaya untuk meningkatkan kemampuan belajar siswa kelas I SD dalam proses penjumlahan dan pengurangan bilangansangat dibutuhkan metode dan alat bantu yang tepat. Siswa Kelas I tidak akan berhasil dalam pembelajaran apabila hanya menghafal konsep. Perlu diingat bahwa siswa Kelas I masih identik dengan dunia bermain dan sangat mengenal dengan benda-benda lingkungan sekitarnya. Jadi alangkah baiknya bila dalam proses pembelajarannya juga menggunakan alat bantu benda-benda kongkrit disekitar sekolah.

Sebelum penelitian tindakan kelas dilaksanakan peneliti dibantu beberapa guru melakukan Observasi lapangan sebagai tindakan awal. Kegiatan ini dilakuakan untuk mengetahui seberapa besar tingkat ketuntasan belajar siswa dalam melakukan operasi penjumlahan dan pengurangan bilangan dalam pembelajaran Matematika. Dari kegiatan Observasi awal ini diperoleh data ulangan sebagai berikut:

1. Siswa yang memperoleh nilai $>70$ ada 7 siswa kurang lebih 35\%

2. Siswa yang memperoleh nilai $<70$ ada 13 siswa kurang lebih $65 \%$

Dari data tersebut dapat disimpulkan bahwa operasi penjumlahan dan pengurangan bilangan belum berhasil.

Kemudian peneliti mencoba untuk meningkatkan prestasi belajar siswa dalam mengoperasionalkan penjumlahan dan pengurangan bilangan dengan menggunakan alat bantu benda-benda kongkrit di sekitar sekolah setelah dilakukan penelitan tindakan kelas peneliti mengambil evaluasi dari masing-masing silkus dengan tujuan untuk mengetahui ada tidaknya peningkatan prestasi belajar siswa. Berdasarkan hasil evaluasi pembelajaran dalam siklus II dengan standart nilai terendah 70 , siswa yang memperoleh nilai > 70 sebanyak 18 siswa atau kurang lebih $90 \%$ sedangkan hasil evaluasi pada siklus II dengan standart nilai yang sama, semua siswa memperoleh nilai $>70$ atau $85 \%$. Dari uraian di atas dapat disimpulkan :
1. Nilai evaluasi Silkus I dan Siklus II mengalami peningkatan.

2. dengan alat bantu benda-benda kongkrit siswa dapat mengoperasionalkan penjumlahan dan pengurangan bilangan.

3. Standart kelulusan belajar tercapai.

2. Siswa mampu mengoperasionalkan penjumlahan dan pengurangan bilangan.

Penggunaan benda-benda kongkrit dalam mengoperasionalkan penjumlahan dan pengurangan bilangan ini dilaksanakan karena siswa atau subyek penelitian belum mampu mengoperasionalkan penjumlahan dan pengurangan tanpa alat bantu. Pada pembelajaran siswa diberi arahan dari instruksi cara menggunakan alat peraga sehingga dapat memperlancar proses pembelajaran. Dengan demikian pembelajaran dengan memanfaatkan alat bantu peraga harus dapat dilakukan oleh subyek penelitian.

Pembelajaran dalam pertemuan I diarahkan pada konsep dasar penggunaan alat bendabenda kongkrit dalam pengoperasian penjumlahan dan pengurangan bilangan dengan hasil kurang dari 20 sesuai dengan perkembangan berfikir anak pada pembelajaran pertemuan I subyek penelitian diarahkan untuk aktif menggunakan alat peraga benda-benba kongkrit. Dalam pembelajaran ini diharapkan siswa merasa senang dan tidak merasa takut dalam mengoperasionalkan penjumlahan dan pengurangan bilangan dalam pembelajaran Matematika.

Kegiatan pembelajaran yang berlangsung dalam pertemuan I dan pertemuan selanjutnya terlihat sunyek penelitian nampak memahami konsep penjumlahan dan pengurangan bilangan yang diawali dari penjumlahan dan pengurangan 2 angka sampai 3 angka. Siswa kelas I merupakan pondasi sekolah dasar 6 tahun. Apabila pondasi dibangun dengan baik dan konsep yang benar maka lulusan / Out Put akan berhasil.

Benda-benda kongkrit yang digunakan sebagai alat bantu penjumlahan dan pengurangan bilangan merupakan alat bantu sementara sebagai penanaman konsep belajar. Apabila siswa sudah berhasil menguasai konsep, maka alat bantu berupa benda-benda kongkrit akan dihilangkan. 
SIMPULAN.

Berdasarkan hasil analisis dan Hopkins. D, 1993. A Teacher Guide To pembahasan tentang upaya meningkatkan kemampuan siswa kelas I dalam mengoperasionalkan penjumlahan dan pengurangan bilangan pada pembelajaran Matematika dengan bantuan benda-benda kongkrit dapat disimpulkan sebagai berikut:

Siswa yang pada awalnya merasa takut dan bingung dengan pembelajaran Matematika, melalui alat bantu benda-benda kongkrit rasa percaya diri siswa timbul dan merasa senang terhadap pembelajaran Matematika terutama tentang mengoperasionalkan penjumlahan dan pengurangan bilangan.

Siswa dapat menggunakan benda-benda kongkrit dengan baik dalam mengoperasionalkan penjumlahan dan pengurangan bilangan pada pembelajaran Matematika.

.Pembelajaran dengan menggunakan alat bantu benda-benda kongkrit di sekitar sekolah dapat meningkatkan kemampuan siswa kelas I dalam mengoperasionalkan penjumlahan dan pengurangan bilangan dengan hasil sampai 20 .

Hal ini dibuktikan dengan hasil evaluasi siklus I menunjukkan standart ketuntasan belajar mencapai $90 \%$ dan siklus II seluruh siswa mengalami ketuntasan belajar.

Kegiatan pembelajaran yang dilaksanakan menjadi lebih menarik dan menyenangkan bagi siswa. Beban Orang tua siswa menjadi lebih ringan karena benda-benda disekitar sekolah tidak harus dibeli dan mudah mendapatkannya.

\section{DAFTAR PUSTAKA}

Classroom Research Buckingham : Open Unuversity Press. Hamalik, 2002. Pendekatan Guru Kurikulum Berbasis Kompetensi. Bandung : Algensondo

Meier.2002 Active Learning. Boston ; Allyn and Bacon.

Mulyasa E, 2002. Kurikulum Berbasis

Kompetensi Bandung, Rosda Karya.

Purwodarminto, Prof.Dr. 1988. Kamus Bahasa

Indonesia. Jakarta Dep Dik Bud.

Wardhani,2004. PPPG. Jakarta : LIPI

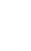


Volume 3 Nomor 2, Halaman 1-77, Juli-Desember 2018

RISTEKDIK / Jurnal Bimbingan dan Konseling

P-ISSN: 2527-4244, E-ISSN : 2541-206X 